\title{
The oldest species of the relic extant genus Mesochria from Eocene Fushun amber of China (Diptera: Anisopodidae: Mycetobiinae)
}

\author{
Ryszard Szadziewski, Jacek Szwedo, Elżbieta Sontag, and Bo Wang
}

\begin{abstract}
A new species - Mesochria fani Szadziewski and Szwedo sp. nov. - is described from Eocene Fushun amber. This is the oldest record of the genus Mesochria, which includes 10 extant species living in the tropics of the Oriental and Afrotropical regions. Fossil records of the genus from Miocene Dominican amber (20 Ma) and Eocene Fushun amber $(50 \mathrm{Ma})$ indicate that this extant group is relictual, and that during its evolution it had a wider, pantropical distribution.
\end{abstract}

Ryszard Szadziewski. Department of Invertebrate Zoology and Parasitology, University of Gdańsk, 59, Wita Stwosza Street, PL80-308 Gdańsk, Poland. ryszard.szadziewski@biol.ug.edu.pl Jacek Szwedo (corresponding author). Department of Invertebrate Zoology and Parasitology, University of Gdańsk, 59, Wita Stwosza Street, PL80-308 Gdańsk, Poland. jacek.szwedo@biol.ug.edu.pl Elżbieta Sontag. Department of Invertebrate Zoology and Parasitology, University of Gdańsk, 59, Wita Stwosza Street, PL80-308 Gdańsk, Poland. elzbieta.sontag@biol.ug.edu.pl Bo Wang. Nanjing Institute of Geology and Palaeontology, Chinese Academy of Sciences, No.39 East Beijing Road, Nanjing 210008, China; Steinmann Institute, University of Bonn, 53115 Bonn, Germany. bowang@nigpas.ac.cn

Keywords: Diptera; Anisopodidae; amber; Fushun; pantropical; new species

Submission: 21 February 2015 Acceptance: 27 March 2016

\section{INTRODUCTION}

Nematoceran dipterans of the family Anisopodidae Knab, 1912 (wood gnats, window-gnats) are common flies in forests, feeding on flowers or sap exuding from trees. They are found on all continents except Antarctica; they are less numerous on islands. Adults are small to medium-sized (usually
4-12 $\mathrm{mm}$ ), with a small, rounded head and short mouthparts. The compound eyes are dichoptic or holoptic. Ocelli are present and form an equilateral triangle. The slender antennae with 14 flagellomeres vary from relatively short to longer than the head and thorax together. The wings are wide, with two or three median branches, sometimes with distinct stigma. The legs are relatively long,

http://zoobank.org/FD492493-D047-4158-9ECA-213E7D7076F6

Szadziewski, Ryszard, Szwedo, Jacek, Sontag, Elżbieta, and Wang, Bo. 2016. The oldest species of the relic extant genus Mesochria from Eocene Fushun amber of China (Diptera: Anisopodidae: Mycetobiinae). Palaeontologia Electronica 19.1.12A: 1-11 palaeo-electronica.org/content/2016/1453-mesochria-from-fushun-amber 
with distinct tibial spurs. Larvae are saprophagous, usually living in decaying or fermenting organic matter. The family Anisopodidae comprises 25 genera with 196 species, including several described fossil taxa (Oosterbroek, 2006; Thompson, 2006; Pape et al., 2011; Lukashevich, 2012). With the transferral of Eopleciidae Rohdendorf, 1946 and Sinotendipedidae Hong and Wang, 1990 to Anisopodidae (Ansorge and Krzemiński, 1995; Pape et al., 2011), as well as the genus Tega Blagoderov et al., 1993 from Cramptonomyidae Hennig, 1969 (Lukashevich, 2012), the fossil record of this family is represented by 18 fossil genera, 3 extant genera and 47 species (Evenhuis, 2014). The internal subdivisions of Anisopodidae are still a matter of discussion (Amorim and Grimaldi, 2006; Oosterbroek, 2006; Thompson, 2006; Pape et al., 2011; Lukashevich, 2012).

The oldest fossil of the Anisopodidae - Mesorhyphus rhaeticus Rohdendorf, 1962 - comes from the Ak-Bulak-Say locality, Sogyuty, near Lake Issyk-Kul, Dzhil Formation, Kyrgyzstan, which is aged Hettangian/Sinemurian, Early Jurassic (Rohdendorf, 1962; Rasnitsyn and Zherikhin, 2002; PaleoBioDB, 2016). Various extinct genera are reported from Jurassic and Cretaceous deposits of Asia and Europe (Evenhuis, 1994, 2014). A few species are known from Eocene Baltic amber, but also from sedimentary deposits in England and North America (Evenhuis, 1994, 2014). The Miocene record consists of findings in fossil resins of the New World, as well as in sedimentary deposits from North America and Europe (Evenhuis, 1994, 2014). The general chronological and stratigraphic distribution pattern of Anisopodidae illustrates its long and complicated evolutionary history.

Some enigmatic taxa placed in Anisopodidae (= Rhyphidae Newman, 1834) were described from Fushun amber by Hong (1981). A new genus and new species - Caloneura plectilis Hong, 1981 was proposed, with a strange wing venation, resulting from its misinterpretation, as one wing overlapped the other one (Hong, 1981, p. 91, figures 96 and 97-IV). Subsequently, Evenhuis (1994, 2014) replaced the preoccupied generic name with Hongocaloneura Evenhuis, 1994: 282 and transferred it to unplaced nematocerous flies. Hong (2002) claimed that his interpretation of the wing venation was correct and established the new family Hongocaloneuridae Hong, 2002 in the Anisopodoidea Knab, 1912. Later, Zhang (2007) commented that the wing venation of Hongocaloneura plectilis, with four branches of $\mathrm{M}$, had never been reported among known Diptera. Another taxon ascribed to Anisopodidae from Fushun amber - Eoanisopodites fushunensis Hong, 2002 appears to be an unavailable name, as this species was proposed after 1999 without any mention of the type depository (ICZN, 1999; Evenhuis, 2014).

The traditional subfamily Mycetobiinae Crampton, 1924 is often treated as a separate family Mycetobiidae of worldwide distribution, with 5 genera and about 20 extant species. Members of the subfamily are robust, small flies, 4-7 $\mathrm{mm}$ long, with a transparent wing membrane, d-cell absent, and an $M$ vein with 2 branches. The head has three ocelli arranged in a triangle on the frons. The antennae are relatively short, with 14 flagellomeres. The proboscis is well-developed, and the 4-segmented palpus short. The thorax is convex. The claws are similar on all the legs; the small, simple, empodium is reduced. Larvae usually are found in moist habitats, in rotting or fermenting organic matter, and are common in exuding treesap and rot holes (Krivosheina, 1997; Oosterbroek, 2006; Thompson, 2006).

The purpose of the present paper is to describe the oldest species of the extant genus Mesochria Enderlein, 1910, from early Eocene Fushun amber. The only fossil species of Mesochria known so far was reported from Miocene Dominican amber (Grimaldi, 1991).

\section{MATERIAL AND METHODS}

The Fushun amber specimen comes from the layers of the West Opencast Coalmine (Xilutian Opencast Coalmine). The West Opencast Coalmine $\left(41^{\circ} 50^{\prime} \mathrm{N}, 123^{\circ} 54^{\prime} \mathrm{E}\right)$, located to the south of Fushun City, Liaoning Province, China (Figure 1.1), is the largest opencast coalmine in Asia, but after more than 110 years of mining, it is now exhausted and being reclaimed (Figure 1.3,1.4). The coal and oil shales are found in a relatively small east-westtrending exposure of Mesozoic and Cenozoic sedimentary and volcanic rocks surrounded by Precambrian terrain consisting mainly of granitic gneiss (Johnson, 1990; Wu et al., 2002). These continental sequences consist of swampy to fluviodeltaic and tuffaceous sediments that were deposited in the basin during the early Palaeogene (Hong et al., 1980; Johnson, 1990; Yang and Li, 1997; Wu et al., 2002). The mining district in the Fushun basin contains the Palaeocene Laohutai and Lizigou formations and the Eocene Guchengzi, Jijuntun, Xilutian, and Gengjiajie formations (Figure 1.2). The amber-bearing Eocene Guchengzi Formation includes thick coal beds intercalated with 

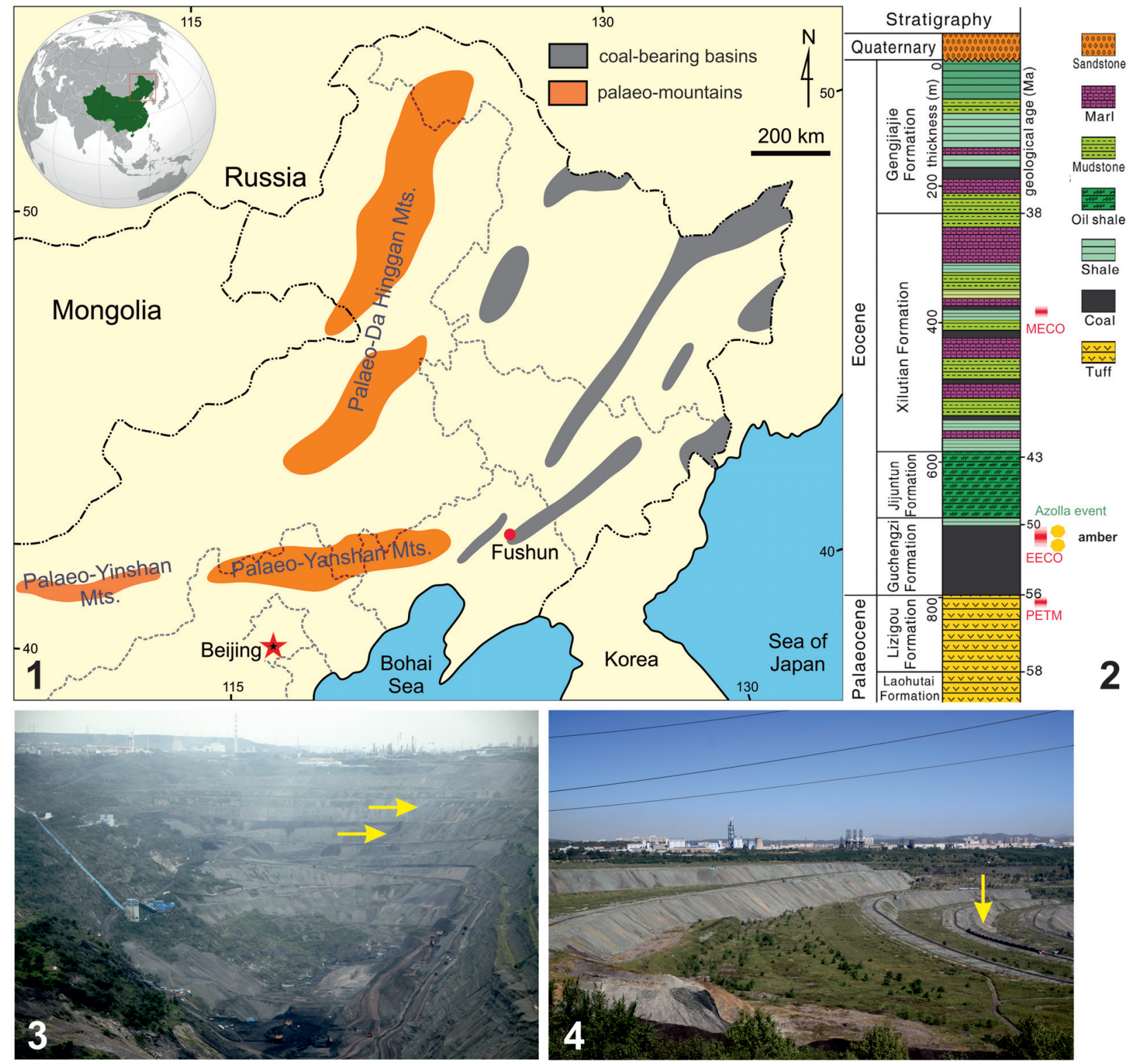

FIGURE 1. 1, Fushun fossil site location and palaeogeographic setting of north-eastern China during the Eocene; Palaeotopographic reconstruction after Wang H. (1995); 2, stratigraphic sequence of the West Opencast Coalmine. The yellow heptagons indicate amber-bearing layers in upper section of the Guchengzi Formation. PETM - Palaeocene-Eocene Thermal Maximum (approximately $55 \mathrm{Ma}$ ); EECO - Early Eocene Climatic Optimum (51-53 Ma); MECO - Middle Eocene Climatic Optimum (approximately 41.5 Ma); 3, View of the West Opencast Coalmine, from the east, 3 September 2013; arrows indicate amber-bearing strata; 4, View of reclamation works in the West Opencast Coalmine from the west, 5 September 2014.

carbonaceous shale (Wu et al., 2001; Meng et al., 2012, Wang, B. et al., 2014).

The West Opencast Coalmine was the largest amber deposit in China. The Fushun amber-bearing strata were the middle and upper coal beds of the Guchengzi Formation, assigned to an earlymiddle Ypresian age (51-55 Ma) and constrained by the palaeofloras (Wang, Q. et al., 2010; Quan et al., 2011), palaeomagnetic considerations and isotopic dating (Zhao et al., 1994; Quan et al., 2011). The palaeoclimate in the early Eocene in Fushun is reconstructed as moist subtropical, with variability in seasonal precipitation (very probably a monsoonal system), with dry and wet seasons (Quan et al., 2011, 2012; Wang, D., et al. 2013). The estimated mean annual temperature varied between 
$15-21^{\circ} \mathrm{C}$; the coldest month mean temperature varied between $9-14^{\circ} \mathrm{C}$ and the warmest month mean temperature varied between $19-25^{\circ} \mathrm{C}$. The mean annual precipitation is estimated as having varied between 650-1500 mm (Wang, Q. et al., 2010; Quan et al., 2011, 2012). These estimations concerns Guchengzi Formation and are based on floral elements (palynofloras) preserved with use of the principle of coexistence approach (CA; Mosbrugger and Utescher, 1997) based on the concept of "nearest living relative (NLR) philosophy"; Quan et al. (2012) deals also with leaf physiognomical analyses for the reconstructions and habitat conditions discussed. The climate was slightly cooler than that of coeval Europe (Mosbrugger et al., 2005; Zachos et al., 2008, Wang, Q. et al., 2010).

The colour of Fushun amber could vary from honey, light yellow, transparent, through various varieties of orange, cherry and cognac, translucent to opaque, patchy and non- transparent forms of dappled earth-amber. This variety is also related to the depositional conditions. The amber pieces are usually small, seldom longer than $10 \mathrm{~cm}$. Fushun amber is naturally autoclaved as the amber-bearing coal deposits were affected by a massive intrusion of basic magmas in the Oligocene (Wu et al., 2000; Wang, X. et al., 2001) so that the amber was heated during diagenesis, like Burmese amber (Shi et al., 2012). The Fourier transform infrared (FTIR) spectrum of Fushun amber shows characteristics of cupressaceous-araucarian resins (Tappert et al., 2013), which suggest Cupressaceae (especially Metasequoia) as the mother plant of the resin. Fragments of Metasequoia are not only the most common plant inclusions in Fushun amber but also very frequent as compressions in the amber-bearing and succeeding layers, supporting this interpretation (Wang, B. et al., 2014).

Fushun amber contains a diverse, well-preserved fossil arthropod fauna and abundant botanical and other inclusions such as leaves, fungi and even mammalian hairs. In addition, some microinclusions, such as palynomorphs and testate amoebae, are frequently found in Fushun amber (Wang, B. et al., 2011, 2014). Arthropod inclusions cover an impressive array, including 22 orders and more than 80 families (Wang, B. et al., 2011, 2014).

The piece of amber under scrutiny here comes from the collections of the Nanjing Institute of Geology and Palaeontology, Chinese Academy of Sciences, Nanjing, China. Fresh amber coated in thick coal dust was ground and polished manually with a series of wet silicon carbide abrasive papers to remove the opaque surface and to mini- mize light reflections during further investigation. The specimen was examined under Olympus SZ11 and SZ12 stereomicroscopes and an Olympus BX43 microscope. Photographs were taken with a Nikon DXM1200 digital camera connected to the above stereomicroscopes and with a Zeiss Discovery V20 system.

According to Recommendation 40A of the Code (ICZN, 1999) the name of family is correctly cited as 'Anisopodidae Knab, 1912'. We follow here the proposition by Thompson (2006) to treat Mesochria (including Neomesochria Amorim and Tozoni, 1994) in the traditional concept as defined by the fusion of wing veins $R_{2+3}$ to $R_{1}$. Morphological terms are adopted from Thompson (2006).

\section{SYSTEMATIC PALAEONTOLOGY}

Order DIPTERA Linnaeus, 1758

Suborder NEMATOCERA Duméril, 1805

Infraorder BIBIONOMORPHA Hennig, 1954

Family ANISOPODIDAE Knab, 1912

Subfamily MYCETOBIINAE Crampton, 1924

Genus MESOCHRIA Enderlein, 1910

Type species. Mesochria scottiana Enderlein, 1910: 65, by original designation.

Mesochria fani Szadziewski and Szwedo sp. nov. zoobank.org/A59ADD22-AF4B-4033-A0BE-AA0547449AA5

Etymology. The specific name is dedicated to Mr. Yong Fan, the director of the Fushun Amber Institute, in recognition of his important contribution to the study of Fushun amber.

Material examined. Holotype male, NIGP156988, Fushun amber. Deposited in the collections of the Nanjing Institute of Geology and Palaeontology, Chinese Academy of Sciences, Nanjing, China. Specimen is slightly distorted and carbonized, due to preservation conditions of amber ( $\mathrm{Wu}$ et al., 2000; Wang, X. et al., 2001), i.e., natural heating (autoclaving) in the deposit, which is often affecting amber inclusions from Fushun.

Diagnosis. The species is characteristic in having well-developed anal veins, the median fork much longer than the basal stem, the costal vein extending one third of the way between apices $R_{4+5}$ and $M_{1}$, and the mid leg with two tibial spurs. Fossil $M$. neotropica from Dominican amber differs in having the median fork slightly shorter than the basal stem, the costal vein ending halfway between $R_{4+5}$ and $M_{1}$, no anal veins, and the mid leg with one tibial spur. Both fossil species are much smaller than extant members of the genus. 
Description. Male. Body dark, altered in amber, length $4.1 \mathrm{~mm}$. Natural colours not preserved. Left mid leg separated from thorax more robust than unnaturally slender right leg (Figure $2.1,2.5$ ). Distal flagellomeres missing, lost during preparation.

Head barely visible (Figure 2.3). Eyes bare, very probably touching or narrowly separated. Ocelli on raised tubercle present. Antenna apparently with 14 more or less cylindrical flagellomeres. Proboscis (Figure 2.3.) short. Palpus 4-segmented, with distal three segments well visible. Fourth palpal segment cylindrical with evenly pointed apex, 4 times longer than third one (Figure 2.3, 2.4).

Scutum barely preserved. Scutellum bearing 4 marginal bristles.

Wing typical of the genus (Figure 2.2, 2.7): length measured from base $2.9 \mathrm{~mm}$. Wing membrane hyaline. Costal vein distinctly extending one third of the way between apices $R_{4+5}$ and $M_{1}$. Subcostal vein bare, ending in $C$ slightly proximal to base of radius. Radial sector Rs setose. Veins $R_{1}$ and $R_{2+3}$ convergent, contiguous apically. Median fork distinctly longer than basal stem (1.8 times). Cross veins complete. Two distinct anal veins present.

Fore and hind tibiae with single apical spur. Mid tibia with two apical spurs. Hind tibia with distinct tibial comb composed of dense row of setae. Claws small, equal, apices bifid; empodium absent. Measurements are given in Table 1 .

Male genitalia barely visible (Figure 2.5, 2.6). Gonocoxites large, fused. Cerci well developed, long.

Female unknown.

Age and occurrence. Early Eocene, Guchengzi Formation, Fushun amber. Xilutian coal mine, Fushun, Liaoning, China $\left(41.8^{\circ} \mathrm{N}, 123.9^{\circ} \mathrm{E}\right.$; palaeocoordinates $\left.43.5^{\circ} \mathrm{N}, 116.0^{\circ} \mathrm{E}\right)$.

\section{DISCUSSION}

The male of the new species is very similar to the female of fossil Mesochria neotropica Grimaldi, 1991 from Miocene Dominican amber. The colouration cannot be used for identification as it is not preserved in inclusions from Fushun amber. The only differences are in the wing venation and in the numbers of tibial spurs on the mid leg (see diagnosis). Extant species are distinctly larger with wing lengths over $4.0 \mathrm{~mm}$. Both fossil species are smaller with wing lengths from 2.9 to $3.1 \mathrm{~mm}$.

The clear definition and unambiguous set of character of the Mesochria Enderlein and related genera are still far from resolution. The generic key of Thompson and Rogers (1992) gave the features of all modern genera placed in the family at that time. Later, the genus Neomesochria Amorim and Tozoni, 1994 was proposed combining number of New World and New Caledonia species of the genus Mycetobia Meigen, 1818, comprising also the fossil Mesochria neotropica Grimaldi, 1991. This statement was argued by Thompson (2006), as according to his opinion the genus Neomesochria lacks any synapomorphy, and the only known to that date Mesochria neotropica venation characters, i.e., terminal $R_{2+3}$ fused to $R_{l}$, places it clearly in the genus Mesochria. Number of species are known exclusively from type specimens with very brief and/or incomplete descriptions. The constituting features of the genus Mesochria are: terminal $R_{2+3}$ fused to $R_{l}, M$ two-branched; discal cell absent, metatibia with apical comb, and additionally, contiguous state of the male eyes (Michelsen, 1999; Thompson, 2006). The other distinguishing features are based on coloration of particular elements of body, but these data are lacking for some modern species (Thompson, 2006). Very little is known on the biology of Mesochria. The stout hooks on the $8^{\text {th }}$ abdominal segment are present as five pairs in Mesochria (Thompson, 2006); pupal skin of Mesochria medicorum Edwards, 1928b, was obtained from rotting banana fibre in Ghana (Edwards, 1928b; Keilin and Tate, 1940). Its sistergroup, Mycetobia is saprophagous and live in fermenting saps runs or slime fluxes from wounds in trees or in tree holes (Keilin, 1919; Keilin and Tate, 1940; Krivosheina, 1997).

Ten extant species of Mesochria are known from Fiji (M. schlingeri Thompson, 2006; M. vulgaris Thompson, 2006), Samoa (M. buxtoniana Edwards, 1928a), Java (M. cinctipes de Meijere, 1913), Borneo (M. intermedia Edwards, 1931), Madagascar (M. sylvatica Stuckenberg, 1961; M. griveaudi Stuckenberg, 1961), the Seychelles ( $M$. scottiana Enderlein, 1910), Ghana (M. medicorum Edwards, 1928b) and the Democratic Republic of Congo (Zaire) (M. congoensis Tollet, 1956) - Figure 3. During the Palaeogene and Neogene the genus was more widely distributed, in the lower Eocene it was present in North China (M. fani, present report) and in the Miocene in the Caribbean Region ( $M$. neotropica Grimaldi, 1991). The genus Mesochria was exemplified as illustrating the tropical Gondwanan track (Matile, 1990) with sporadic "recent extensions" into the Holarctic (Amorim and Pires, 1996; Cranston, 2005). The tropical Gondwanan track (Matile, 1990) was proposed for explanation of Gondwanan distributions of groups, which phylogenies are concordant with subsequent breakups of Gondwanan landmasses 

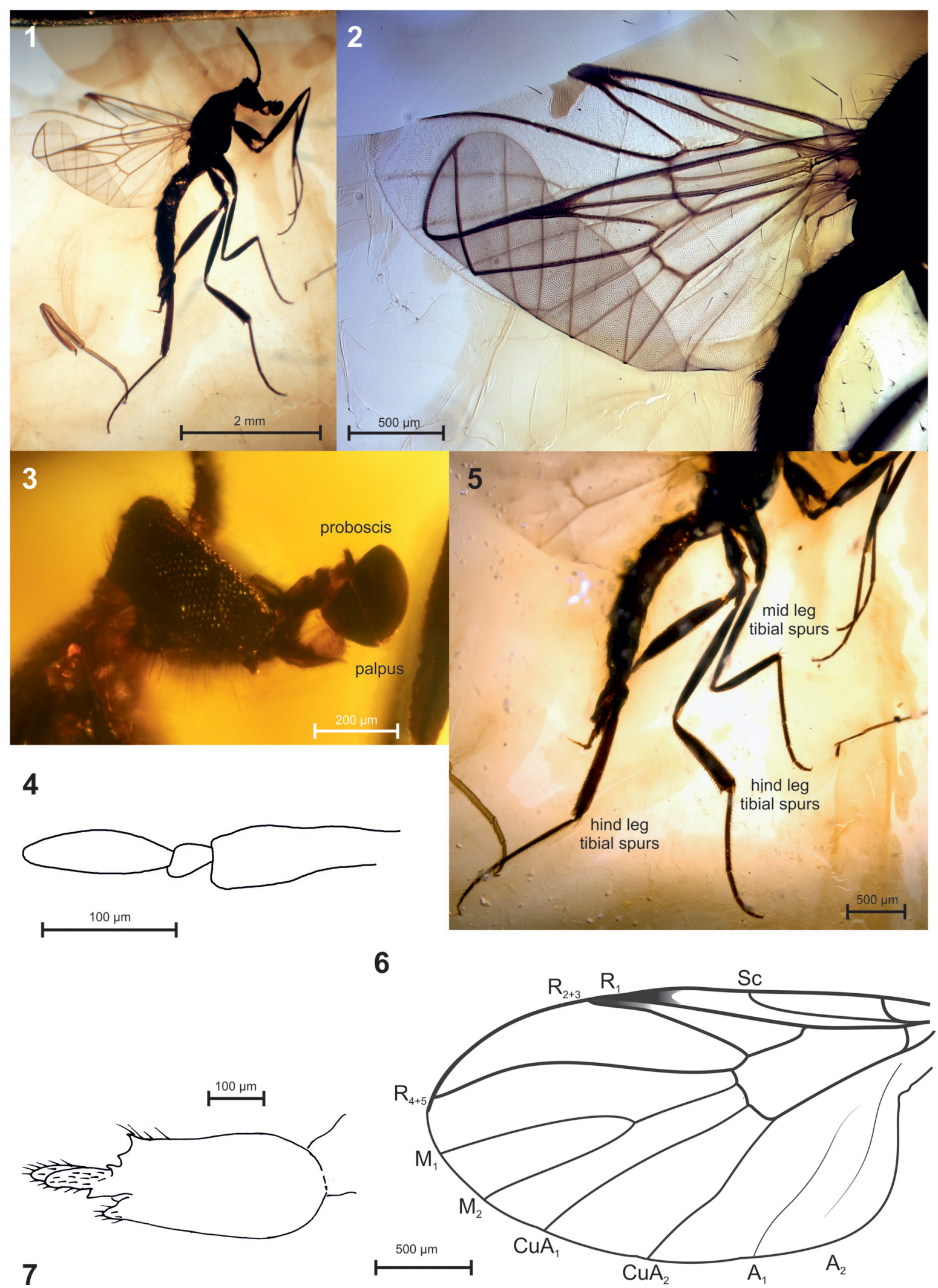

FIGURE 2. Holotype male of Mesochria fani Szadziewski and Szwedo, sp. nov. 1, habitus, lateral aspect; 2, wings; 3, mouthparts; 4, palpus; 5, legs; 6, wing reconstructed; 7, genitalia, lateral aspect. 
TABLE 1. Length measurements of legs (in $\mathrm{mm}$ ). TR (ta1/ta2) - tarsal ratio; fe - femur; ti - tibia; ta1-ta5 - tarsomeres $1-5$.

\begin{tabular}{lccccccccc}
\hline & TR & fe & ti & ta1 & ta2 & ta3 & ta4 & ta5 \\
\hline Fore leg & 2.8 & 0.90 & 0.95 & 0.61 & 0.22 & 0.15 & 0.09 & 0.09 \\
Mid leg & 2.7 & 1.00 & 0.88 & 0.60 & 0.22 & 0.16 & 0.09 & 0.09 \\
Hind leg & 3.1 & 1.18 & 1.37 & 0.81 & 0.26 & 0.16 & 0.09 & 0.09 \\
\hline
\end{tabular}

(dated minimally to the early Cretaceous). In fact, this track, was recognized earlier by Harrison (1928), a perceptive early adopter of the Wegener paradigm. Vast majority of the extinct Anisopodidae is known exclusively from the Northern Hemisphere, since the early Jurassic to the Pleistocene (Evenhuis 1994, 2014). Within the Anisopodidae, as Matile (1990) and Amorim and Pires (1996) observed, extant members have fossil material from the northern hemisphere, but tropical Gondwanan track is seen in the pairs of sister genera Eogaster (Afro-Oriental)/Olbiogaster (Neotropical), and Mesochria (Afro-Oriental)/Neomesochria (Neotropical/Australian). The problem of so-called Gondwanan taxa was widely discussed (Eskov,
1992; Sanmartín and Ronquist, 2004; McCarthy et al., 2007), with various explanations given. Vicariance and long distance dispersion events are allopatry based, geographical explanations for the process of speciation and, although both had a role in the diversification of lineages, often are treated as exclusive alternative models (Crisp et al., 2011; Gillespie et al., 2012). The present finding of the oldest species of Mesochria from the early Eocene of the Northern Hemisphere challenges tropical Gondwanan track hypothesis (Matile, 1990). We believe, the present distribution of Mesochria could result from its long history, with both vicariance and long dispersal events. More mechanisms could be involved in explanation of their distribution and

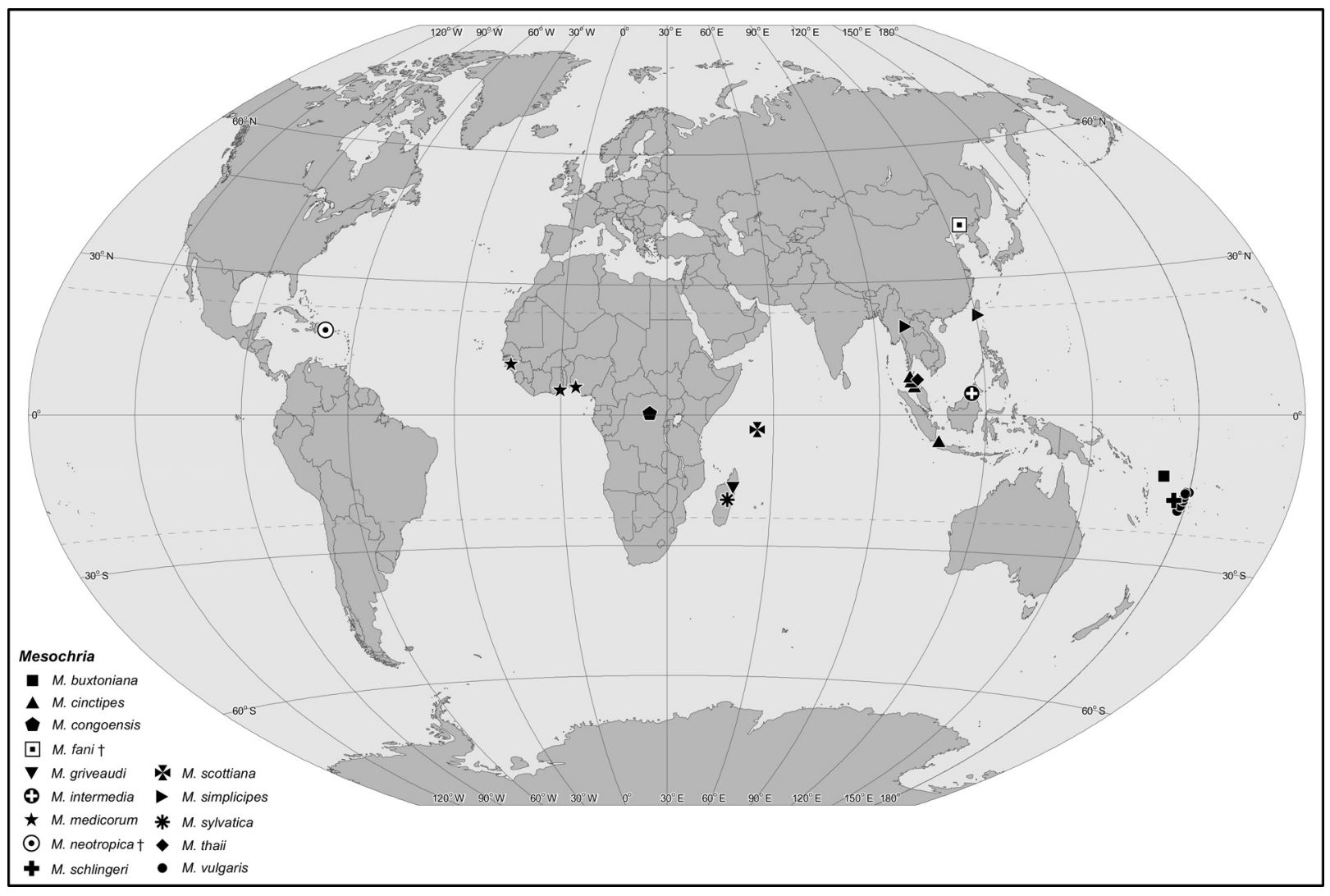

FIGURE 3. Geographical distribution of fossil and extant species of the genus Mesochria. 
presence of the known fossils. The most rates of taxa formation are observed in such locations in which the struggle for existence against abiotic factors is reduced, as proposed by concepts of zonal stratification (Zherikhin, 1978) and phytospreading (Meyen, 1987a, 1987b), which are the extensions of Darlington's "equatorial pump" concept (Darlington, 1957, 1959). The model of the "tropical pump" assumes that formation of the new taxa is restricted mainly to the tropical equatorial zone, and proliferated descendants oust the ancestors to the extratropical regions. The concept of zonal stratification assumes that due to deterioration of more uniform climatic and ecological conditions of the late Cretaceous-early Palaeogene times and re-organisation of biosphere, with separation and differentiation of bioclimatic zones numerous late Mesozoic and early Cenozoic taxa gone extinct (Zherikhin, 1978; Eskov, 1996). The phenomenon of phytospreading (Meyen, 1987a, 1987b; Eskov, 1996 ) is not so much geographic as ecological in nature. It assumes that the newly formed taxa follow by anisotropic propagation ("spreading") from regions of the world where the climatic conditions are most into regions with harsher abiotic conditions. The late Mesozoic and early Cenozoic were characterised by weak climatic zonality (Gornitz, 2009), which resulted in intermittent and ceasing operation of "equatorial pump" mechanism (Eskov, 1995, 1996), and increasing role of second-rank gradients (humid-arid, lowland-highland, etc.), enabling the phytospreading mechanism operant in the regime of Dobruskina's (1982) diffuse centres of speciation. This could trigger the diversification of Mesochria. Subsequent, late Palaeogene and early Neogene transition from azonal to zonal epoch, establishment of a new climatic regime and biotic reorganization, resulting in concentration of Mesozoic-Palaeogene relics in the tropical and subtropical zones.

All the modern species of the genus Mesochria are present within the belt with mean annual temperature above $25^{\circ} \mathrm{C}$ and with mean annual precipitation over $1600 \mathrm{~mm}$ (Peel et al., 2007; CCKP, 2015; SAGE, 2015). The new species comes from the amberiferous layers of the Guchengzi Formation. The reconstructed Mean Annual Temperature for these layers are 15.2$15.6^{\circ} \mathrm{C}$ for the middle and $17.9-21.1^{\circ} \mathrm{C}$ for the upper; Mean Annual Precipitation 1035-1362 mm for the middle and 897-1355 $\mathrm{mm}$ for the upper (Quan et al., 2011, 2012). However, some recent species were reported from more elevated areas, where local MAT and MAP values could be decreased and better correspond to the conditions reconstructed for the Early Eocene Fushun area. Most of the amber specimens were found in the upper layer of the Guchengzi Formation, according to Quan et al. (2012) these strata were deposited during the Early Eocene warming period. In our opinion, presence of fossil Mesochria in Fushun amber corroborates the hypothesis on subtropical climate, or at least fluctuation of climate during the terminal early Eocene as already suggested by Quan et al. (2012).

Despite of scarcity of biological data on Mesochria, its biological and environmental requirements, limited recent distribution and fossil record some explanations on its evolutionary history can be presented. In our opinion the distributional pattern of the modern Mesochria resulted from concentration of relictual descendants of late Mesozoic-Palaeogene forms in the tropical and subtropical zones. Both vicariance and long distance dispersal events, as well as other evolutionary mechanisms probably shaped the long history of this relictual genus, which, with present finding could be traced back to early Eocene times.

\section{ACKNOWLEDGEMENTS}

We greatly appreciate the efforts of Mr. M. Gąsior, MSc (Museum and Institute of Zoology, Polish Academy of Sciences, Warsaw) for his help with the georeferencing software and map drawing. We wish also to thank Mr. P. Senn (Gdynia) for language advice. B.W. was supported by the National Natural Science Foundation of China (41572010) and a Research Fellowship from the Alexander von Humboldt Foundation.

\section{REFERENCES}

Amorim, D. de S. and Grimaldi, D.A. 2006. Valeseguyidae, a new family of Diptera in the Scatopsoidea, with a new genus in Cretaceous amber from Myanmar. Systematic Entomology, 31:508-516. doi:10.1111/j.1365-3113.2006.00326.x

Amorim, D. de S. and Pires, M.R.S. 1996. Neotropical biogeography and a method for maximum biodiversity estimation, p. 183-219. In Bicudo, C.E.M. and Menezes, N.A. (eds.), Biodiversity in Brazil, a first approach. CNPq, São Paulo.

Amorim, D. de S. and Tozoni, S.H.S. 1994. Phylogenetic and biogeographic analysis of the Anisopoidea (Diptera: Bibiomorpha), with an area cladogram from intercontinental relationships. Revista Brasileira de Entomologia, 38:517-543.

Ansorge, J. and Krzemiński, W. 1995. Revision of Mesorhyphus Handlirsch, Eoplecia Handlirsch and Heterorhyphus Bode (Diptera: Anisopodomorpha, 
Bibionomorpha) from the Upper Liassic of Germany. Paläontologische Zeitschrift, 69:167-172.

Blagoderov, V.A., Krzemińska, E., and Krzemiński, W. 1993. Fossil and recent Anisopodomorpha (Diptera, Oligoneura): family Cramptonomyiidae. Acta Zoologica Cracoviensia, 35:573-579.

CCKP, 2015. The Climate Change Knowledge Portal. The World Bank Group. http://sdwebx.worldbank.org/ climateportal/index.cfm. Last accessed 18 November 2015.

Crampton, G.C. 1924. Remarks on the phylogeny and interrelationships of nematocerous Diptera. Psyche, 31: 238-242.

Cranston, P. 2005. Biogeographic patterns in the evolution of Diptera, p. 274-311. In Yeates, D.K. and Wiegmann, B.M. (eds.), The Evolutionary Biology of Flies. Columbia University Press, New York.

Crisp, M.D., Steven, A., Trewick, S.A., and Cook, L.G. 2011. Hypothesis testing in biogeography. Trends in Ecology \& Evolution, 26:66-72. doi:10.1016/j.tree.2010.11.005

Darlington, P.J. Jr. 1957. Zoogeography: The geographical distribution of animals. Chapman and Hall, London.

Darlington, P.J. Jr. 1959. Area, climate, and evolution. Evolution, 13:488-510.

de Meijere, J.C.H. 1913. Studien über südostasiatiche Dipteren VII. Tijdschrift voor Entomologie, 56:317354.

Dobruskina, I.A. 1982. The Triassic floras of Eurasia. Trudy Geologicheskogo Instituta Akademii Nauk SSSR, 365: 1-196. (In Russian)

Duméril, A.M.C. 1805 (1806). Zoologie analytique, ou méthode naturelle de classification des animaux, rendue plus facile à l'aide de tableaux synoptiques. Allais, Paris.

Edwards, F.W. 1928a. Nematocera. p. 23-102. In Insects of Samoa, 4, Pt 6, (fasc. 2, part) (Diptera), British Museum (Natural History), London.

Edwards, F.W. 1928b. Diptera. Fam. Protorhyphidae, Anisopodidae, Pachyneuridae, Trichoceridae. Genera Insectorum, 190:1-41.

Edwards, F.W. 1931. Diptera Nematocera from the lowlands of North Borneo. Journal of the Federated Malay States Museums, 16:486-504.

Enderlein, G. 1910. The Percy Sladen Trust Expedition to the Indian Ocean in 1905 under the leadership of Mr. J. Stanley Gardiner M.A. III, V - Diptera, Mycetophilidae. Transactions of the Linnaean Society, 14:59-81.

Eskov, K.Yu. 1992. Archaeid spiders from Eocene Baltic amber (Chelicerata: Araneae: Archaeidae) with remarks on the so-called "Gondwanan" ranges of recent taxa. Neues Jahrbuch für Geologie und Paläontologie, Abhandlungen, 158:311-328.

Eskov, K.Yu. 1995. On macrobiogeographic regularities of phylogenesis. Ecosystem reorganisations and evolution of biosphere, 1:199-205. (In Russian)
Eskov, K.Yu. 1996. A test of the "phytospreading" and "zonal stratification" biogeographic models on various groups of arthropods (preliminary results). Paleontological Journal, 29:105-111.

Evenhuis, N.L. 1994. Catalogue of the fossil flies of the World (Insecta: Diptera). Backhuys Publishers, Leiden, The Netherlands.

Evenhuis, N.L. 2014. Family Anisopodidae. In: Catalog of fossil Diptera of the world (Version 2.0). http:// hbs.bishopmuseum.org/fossilcat/ Last updated 23 January, 2014, last accessed 23 March 2016.

Gillespie, R.G., Baldwin, B.G., Waters, J.M., Fraser, C.I., Nikula, R., and Roderick, G.K. 2012. Long-distance dispersal: a framework for hypothesis testing. Trends in Ecology and Evolution, 27:47-56. doi:10.1016/j.tree.2011.08.009

Gornitz, V. (ed). 2009. Encyclopedia of paleoclimatology and ancient environments. Springer, Dordrecht, The Netherlands.

Grimaldi, D. 1991. Mycetobiinae woodgnats (Diptera: Anisopodidae) from the Oligo-Miocene amber of the Dominican Republic and Old World affinities. American Museum Novitates, 3014:1-24.

Harrison, L. 1928. The composition and origins of the Australian fauna, with special reference to the Wegener hypothesis. Report of the $18^{\text {th }}$ Meeting of the Australasian Association for the Advancement of Science, 28:332-396.

Hennig, W. 1954. Flügelgeäder und System der Dipteren unter Berücksichtigung der aus dem Mesozoikum beschriebenen Fossilien. Beitrage zur Entomologie, 4:245-388.

Hennig, W. 1969. Die Stammesgeschichte der Insekten. W. Cramer, Frankfurt a. M.

Hong, Y.C., Yang Z.Q., Wang, S.T., Sun, X.Q., Du, N.Q., Sun, M.R., and Li G.Y. 1980. A Research on the Strata and Palaeontology of the Fushun Coal Field in Liaoning Province. Science Press, Beijing. (In Chinese)

Hong, Y.C. 1981. Eocene fossil Diptera Insecta in amber of Fushun coalfield. Geological Publishing House, Beijing.

Hong, Y.C. 2002. Amber insects of China. Beijing Science and Technology Publishing House, Beijing.

Hong, Y.C. and Wang, W.L. 1990. Fossil insects from the Laiyang Basin, Shandong Province, p. 44-189. In Regional Geological Surveying Team, The stratigraphy and palaeontology of Laiyang Basin, Shandong Province. Shandong Bureau of Geology and Mineral Resources, China.

ICZN, 1999. International Code of Zoological Nomenclature. Fourth edition. International Trust for Zoological Nomenclature, London.

Johnson, E.A. 1990. Geology of the Fushun coalfield, Liaoning Province, People's Republic of China. International Journal Coal Geology, 14:217-236.

Keilin, D. 1919. On the structure of the larvae and the systematic position of the genera Mycetobia Meigen, Ditomyia Winnertz and Symmerus Walker (Diptera, 
Nematocera). Annals and Magazine of Natural History, (9) 3:33-42.

Keilin, D. and Tate, P. 1940. The early stages of the families Trichoceridae and Anisopodidae (= Rhyphidae) (Diptera: Nematocera). Transactions of Royal Entomological Society, London, 90:39-62.

Knab, F. 1912. New species of Anisopidae (Rhyphidae) from tropical America. (Diptera: Nemocera). Proceedings of the Biological Society of Washington, 25:111-113.

Krivosheina, N.P. 1997. Family Mycetobiidae, p. 249254. In Papp, L. and Darvas, B. (eds.), Manual of Palaearctic Diptera. 2. Science Herald, Budapest.

Linnaeus, C. 1758. Systema Naturae per Regna tria Naturae, secundum classes, ordines, genera, species, cum characteribus, differentiis, synonymis, locis. Tomus I. Holmiae: Impensis Direct. Laurentii Salvii.

Lukashevich, E.D. 2012. New Bibionomorpha (Insecta: Diptera) from the Jurassic of Asia. Paleontologicheskii Zhurnal, 3:52-64. (In Russian; English translation, Paleontological Journal, 46:273-287.)

Matile, L. 1990. Recherches sur la systématique et l'évolution des Keroplatidae (Diptera, Mycetophiloidea). Mémoires du Muséum National d'Histoire Naturelle, A, Zoologie, 148:1-682.

McCarthy, D., Ebach, M.C., Morrone, J.J., and Parenti, L.R. 2007. An alternative Gondwana: biota links South America, New Zealand and Australia. Biogeografía, 2:1-11.

Meigen, J.W. 1818. Systematische Beschreibung der bekannten europäischen zweiflügeligen Insekten. Vol. I. Friedrich Wilhelm Forstmann, Aachen.

Meng, Q.T., Liu, Z.J., Bruch, A.A., Liu, R., and Hu, F. 2012. Palaeoclimatic evolution during Eocene and its influence on oil shale mineralisation, Fushun basin, China. Journal of Asian Earth Sciences, 45:95-105. doi:10.1016/j.jseaes.2011.09.021

Meyen, S.V. 1987a. The geography of macroevolution in the higher plants. Obshchaya biologia, 48:291-309.

Meyen, S.V. 1987b. Fundamentals of palaeobotany. Chapman and Hall, London.

Michelsen, V. 1999. Wood Gnats of the genus Sylvicola (Diptera, Anisopodidae): taxonomic status, family assignment, and review of nominal species described By J. C. Fabricius. Tijdschrift voor Entomologie, 142: 69-75.

Mosbrugger, V. and Utescher, T. 1997. The coexistence approach-a method for quantitative reconstructions of Tertiary terrestrial palaeoclimate data using plant fossils. Palaeogeography, Palaeoclimatology, Palaeoecology, 134:61-86.

Mosbrugger, V., Utescher, T., and Dilcher, D.L. 2005. Cenozoic continental climatic evolution of Central Europe. Proceedings of the National Academy of Sciences of the United States of America, 102:1496414969. doi:10.1073/pnas.0505267102
Newman, E. 1834. Attempted division of British insects into natural orders. The Entomological Magazine, 2:379-431.

Oosterbroek, P. 2006. The European Families of the Diptera: Identification, Diagnosis, Biology. KNNV Publishing, Utrecht.

PaleoBioDB 2016. The Paleobiology Database. Revealing the history of life. Anisopodidae. http://paleobiodb.org/ Last visited 23 March 2016.

Pape, T., Blagoderov, V., and Mostovski, M.B. 2011. Order Diptera Linnaeus, 1758. In Zhang, Z.-Q. (ed.), Animal biodiversity: An outline of higher-level classification and survey of taxonomic richness. Zootaxa, 3148:222-229.

Peel, M.C., Finlayson, B.L., and McMahon, T.A. 2007. Updated world map of the Köppen-Geiger climate classification. Hydrology and Earth System Sciences, $11: 1633-1644$. doi:10.5194/hess-11-1633-2007

Quan, C., Liu, Y.S., and Utescher, T. 2011. Paleogene evolution of precipitation in northeast China supporting the middle Eocene intensification of the East Asian monsoon. Palaios, 26:743-753. doi:10.2110/palo.2011.p11-019r

Quan, C., Liu, Y.S., and Utescher, T. 2012. Paleogene temperature gradient, seasonal variation and climate evolution of northeast China. Palaeogeography, Palaeoclimatology, Palaeoecology, 313-314:150161. doi:10.1016/j.palaeo.2011.10.016

Rasnitsyn, A.P. and Zherikhin, V.V. 2002. 4.1. Impression fossils, p. 437-444. In Rasnitsyn, A.P. and Quicke, D.L.J. (eds.), History of Insects. Kluwer Academic Publishers, Dordrecht, The Netherlands.

Rohdendorf, B.B. 1962. Order Diptera, p. 307-345. In Rohdendorf, B.B. (ed.), Fundamentals of Paleontology, 9, Arthropoda-Tracheata and Chelicerata. Academy of Sciences of the USSR, Moscow. (In Russian, English translation: 1991, p. 444-502. Smithsonian Libraries and National Science Foundation, Washington, D.C.)

SAGE 2015. Atlas of the Biosphere. Center for Sustainability and the Global Environment (SAGE), University of Wisconsin-Madison. http://nelson.wisc.edu/ sage/data-and-models/maps.php. Last accessed 18 November 2015.

Sanmartín, I. and Ronquist, F. 2004. Southern Hemisphere biogeography inferred by event-based models: plant versus animal patterns. Systematic Biology, 53:216-243. doi:10.1080/10635150490423430

Shi, G.H., Grimaldi, D.A., Harlow, G.E., Wang, J., Wang, J., Yang, M., Lei, W., Li, Q., and Li, X. 2012. Age constraint on Burmese amber based on U-Pb dating of zircons. Cretaceous Research, 37:155-163. doi:10.1016/j.cretres.2012.03.014

Stuckenberg, B.R. 1961. Records and descriptions of Diptera from Madagascar. Part I. Anisopodidae, and 
Mycetophilidae genus Allactoneura de Meijere. Naturaliste malgache, 12[1960]:123-132.

Tappert, R., McKellar, R.C., Wolfe, A.P., Tappert, M.C., Ortega-Blanco, J., and Muehlenbachs, K. 2013. Stable carbon isotopes of C3 plant resins and ambers record changes in atmospheric oxygen since the Triassic. Geochimica et Cosmochimica Acta, 121:240262. doi:10.1016/j.gca.2013.07.011

Thompson, C. 2006. New Mesochria species (Diptera: Anisopodidae) from Fiji, with notes on the classification of the family. Evenhuis, N.L. and Bickel, D.J. (eds.), Fiji Arthropods IV. Bishop Museum Occasional Papers, 86:11-21.

Thompson, F.C. and Rogers, T. 1992. Sylvicola cinctus (Fabricius), the Hawaiian Wood Gnat, with notes on the family (Diptera: Anisopodidae). Proceedings of the Hawaiian Entomological Society, 31:47-57.

Tollet, R. 1956. Anisopodidae (Diptera Nematocera). Exploration du Parc National Albert. Mission G. F. de Witte, 86:15-34.

Wang, B., Rust, J., Engel, M.S., Szwedo, J., Dutta, S., Nel, A., Fang, Y., Meng, F.-W., Shi, G.L., Jarzembowski, E.A., Wappler, T., Stebner, F., Fang, Y., Mao, L.M., Zheng, D., and Zhang, H.-C. 2014. A diverse paleobiota in Early Eocene Fushun amber from China. Current Biology, 24:1606-1610. doi:10.1016/j.cub.2014.05.048

Wang, B., Zhang, H.C., and Azar, D. 2011. The first Psychodidae (Insecta: Diptera) from the Lower Eocene Fushun amber of China. Journal of Paleontology, 85:1154-1159. doi:10.1666/11-011.1

Wang, D., Lu, S., Han, S., Sun, X., and Quan, C. 2013. Eocene prevalence of monsoon-like climate over eastern China reflected by hydrological dynamics. Journal of Asian Earth Sciences, 62:776-787. doi:10.1016/j.jseaes.2012.11.032

Wang, H. 1995. Atlas of the Paleogeography of China. Cartographic Publishing House, Beijing.

Wang, Q., Ferguson, D.K., Feng, G.-P., Ablaev, A.G., Wang, Y.-F., Yang, J., Li, Y.-L., and Li, C.-S. 2010. Climatic change during the Palaeocene to Eocene based on fossil plants from Fushun, China. Palaeo- geography, Palaeoclimatology, Palaeoecology, 295:323-331.

doi:10.1016/j.palaeo.2010.06.010

Wang, X., Quu, S.-W., Song, C.-C., Kulakov, A., Tashchi, S., and Myasnikov, E. 2001. Cenozoic volcanism and geothermal resources in northeast China. Chinese Geographical Science, 11:150-154.

Wu, C.L., Yang, Q., Zhu, Z.D., Liu, G., and Li, X. 2000. Thermodynamic analysis and simulation of coal metamorphism in the Fushun Basin, China. International Journal of Coal Geology, 44:149-168. doi:10.1016/S0166-5162(00)00008-2

Wu, C.L., Wang, X.G., Liu, G., Li, S.H., Mao, X.P., and Li, X. 2001. Tectonics revolution dynamics study in Fushun basin. Science in China (Series D), 31:476-485. (In Chinese)

Wu, C.L., Wang, X.I., Liu, G., Li, S.H., Mao, X.P., and Li, $X .2002$. Study on dynamics of tectonic evolution in the Fushun Basin, Northeast China. Science in China (Series D: Earth Sciences), 45:311-324.

Yang, X.D. and Li, X.Y. (eds.) 1997. Stratigraphy (Lithostratic) of Liaoning Province. p. 112-176. Multiple Classification and Correlation of the Stratigraphy of China, 21. China University of Geosciences Press, Wuhan. (In Chinese with English abstract)

Zachos, J.C., Dickens, G.R., and Zeebe, R.E. 2008. An early Cenozoic perspective on greenhouse warming and carbon-cycle dynamics. Nature, 451:279-283. doi:10.1038/nature06588

Zhang, J. 2007. Some anisopodoids (Insecta: Diptera: Anisopodoidea) from late Mesozoic deposits of northeast China. Cretaceous Research, 28:281-288. doi:10.1016/j.cretres.2006.05.008

Zhao, C., Ye, D., Chen, B., and Liu, D. 1994. The Northeast Region of China. Tertiary in Petroliferous Regions of China, 3. Petroleum Industry Press, Beijing. (In Chinese with English abstract)

Zherikhin, V.V. 1978. Development and changes of the Cretaceous and Cenozoic faunal assemblages (Tracheata and Chelicerata). Trudy Paleontologicheskogo Instituta Akademii Nauk SSSR, 165:1-198. (In Russian) 